\title{
Penerapan Restorative Justice dalam Penanganan Kasus Kekerasan Terhadap Perempuan Pada Masa Pandemi Corona Virus Disease (COVID-19)
}

\author{
Elsa Rina Maya ${ }^{1, *}$ Hadibah Zachra Wadjo $^{2}$, Farhan Lestaluhu ${ }^{3}$ \\ ${ }^{1}$ Fakultas Hukum Universitas Pattimura \\ elsa.toule@fhukum.unpatti.ac.id ${ }^{1}$ dibawadjo123@gmail.com ${ }^{2} \underline{\text { farhanlestaluh@gmail.com }}^{3}$ \\ *Corespondence Author
}

\begin{abstract}
Abstrak
Kebijakan pemerintah untuk membebaskan wargabinaan dengan persyaratan tertentu sebagai upaya pencegahan mewabahnya Corona Virus Disease (Covid 19) di lembaga pemasyarakatan berimbas pada berkurangnya wargabinaan di dalam suatu lembaga pemasyarakatan, teristimewa pada lembaga pemasyarakatan yang melebihi kapasitas. Pada bagian lain, kebijakan ini juga mesti diikuti dengan kebijakan untuk tidak menambah jumlah kasus-kasus tertentu melalui mekanisme restorative justice, yakni kasus-kasus didiversi dari sistem peradilan pidana, kemudian diselesaikan dengan melibatkan pelaku dan korban serta pihak-pihak yang berkepentingan. Restorative Justice di beberapa wilayah Polres di Maluku mengambil bentuk penyelesaian menurut hukum adat setempat. Hal ini mengindikasikan bahwa restorative justice bukanlah mekanisme yang baru dalam menyelesaikan persoalan-persoalan hukum dalam masyarakat yang masih kental dengan sistem hukum adat. Kasus-kasus yang dapat diselesaikan dengan mekanisme ini adalah kasus-kasus dalam keluarga seperti halnya kekerasan dalam rumah tangga (KDRT). Kasus KDRT merupakan kasus yang kompleks karena melibatkan suami dan isteri yang secara legal terikat dalam lembaga perkawinan, yang sama-sama bekerja untuk membangun rumah tangga. Dengan demikian, mekanisme ini sangat cocok untuk menghindari kehancuran dalam keluarga yang dapat berlanjut dengan perceraian. Namun dalam realitasnya, diterapkan juga dalam kasus-kasus kekerasan terhadap perempuan yang terjadi di luar lingkup keluarga.
\end{abstract}

Kata Kunci : Kekerasan, Perempuan, Restorative Justice.

Naskah dikirim: 27 Desember 2020|Direvisi: 19 Februari 2021|Diterbitkan: 28 Februari 2021 


\begin{abstract}
Government policy to free citizens with certain requirements as an effort to prevent the outbreak of Corona Virus Disease (Covid 19) in penitentiary or correctional institutions has an impact on the reduction of citizens in a correctional institution, especially in correctional institutions that exceed capacity. In other parts, this policy must also be followed by other policy for not to increase the number of certain cases through restorative justice mechanisms, namely cases diversion from the criminal justice system, then resolved by involving perpetrators and victims, and interested parties. Restorative Justice in some areas of the Police in Maluku took the form of settlement according to local customary law. This indicates that restorative justice is not a new mechanism in solving legal issues in a society that is still thick with the customary legal system. Cases that can be solved by this mechanism are cases in the family as well as domestic violence (KDRT). The domestic violence case is complex because it involves a husband and wife who are legally bound in a marriage institution, which both works to build a household. Thus, this mechanism is perfect for avoiding destruction in the family that can continue with divorce. But in reality, it is also applied in cases of violence against women that occur outside of the scope of the family.
\end{abstract}

Keywords: Violence, Women, Restorative Justice.

\title{
Pendahuluan
}

Pandemi Corona Virus Disease tahun 2019 (Covid-19), membawa pengaruh yang sangat besar terhadap seluruh aspek kehidupan manusia. Bukan hanya masalah kesehatan, ataupun masalah ekonomi, tetapi juga masalah penegakan hukum. Berbagai kebijakan telah dilakukan pemerintah untuk mencegah berkembangnya virus tersebut. Salah satu yang sangat kontroversial adalah Peraturan Menkumham Nomor 10 tahun 2020 dan Keputusan Kemenkumham No.19/PK/01/04/2020 untuk mengeluarkan sejumlah narapidana yang dikeluarkan Kementerian Hukum dan HAM. Menteri Hukum dan HAM, Yasonna Laoly memperkirakan sekitar 30.000 sampai 35.000 narapidana dewasa dan anak yang dibebaskan. Mereka yang dikeluarkan adalah Pembebasan Narapidana ini dimaksudkan untuk memotong mata rantai penyebaran Covid-19 karena ruangan penjara yang penuh, bahkan kelebihan kapasitas sehingga tidak memungkinkan untuk menjalankan protokol kesehatan, terutama menjaga jarak, sebagai salah satu cara mencegah penyebaran virus tersebut. 
Laoly menyatakan bahwa kebijakan pembebasan narapidana di tengah pandemi Covid19 yang dilakukan saat ini merupakan rekomendasi dari Perserikatan Bangsa-Bangsa (PBB). ${ }^{1}$ Kebijakan tersebut diambil untuk mencegah para narapidana terinfeksi Covid-19 di dalam lembaga pemasyarakatan dan rumah tahanan negara yang over kapasitas. Dengan demikian, kebijakan ini bukan hanya dilakukan di Indonesia tetapi diberbagai belahan dunia, antara lain, Amerika Serikat membebaskan 8.000 narapidana, Inggris dan Wales 4.000 narapidana, Iran 85.000 narapidana dan 10.000 tahanan politik, Bahrain membebaskan 1.500 narapidana, Israel 500 narapidana, Yunani 15.000 narapidana, Polandia 10.000 narapidana, Brazil 34.000 narapidana, Afghanistan 10.000 narapidana, Tunisia 1.420 narapidana, Kanada 1.000 narapidana, dan Prancis 5.000 narapidana.

Pembebasan dilakukan dengan alasan kemanusiaan karena kondisi di dalam lapas dan rutan sudah sangat kelebihan kapasitas dan kondisi di dalam lapas akan sangat mengerikan jika tidak melakukan pencegahan penyebaran Covid-19. Sampai dengan akhir Mei 2020, sebanyak 39.876 narapidana dan narapidana anak telah dibebaskan dalam program asimilasi dan integrasi. Narapidana yang mengikuti program asimilasi berjumlah sebanyak 37.473 narapidana, 934 di antaranya adalah narapidana anak dan sebanyak 36.593 sisanya adalah narapidana dewasa. Sedangkan narapidana yang mengikuti program integrasi berjumlah 2.403 narapidana. Terdiri dari 2.360 narapidana dewasa dan 43 narapidana anak. ${ }^{2}$

Meskipun demikian, proses penegakan hukum tetap dilakukan terhadap berbagai kasus yang dilimpahkan dalam sistem peradilan pidana, yang tentunya akan tetap menambah jumlah penghuni lembaga pemasyarakatan. Dampak Covid-19 yang mempengaruhi sisi ekonomi dan sosial akan mempengaruhi angka kejahatan dalam masyatakat. Apalagi setelah pembebasan narapidana dalam jumlah yang banyak, yang seharusnya masih berada dalam proses pembinaan, akan memberikan kemungkinan pengulangan tindak pidana oleh mantan narapidana tersebut.

Menghadapi kondisi yang demikian, maka upaya untuk mencegah bertambahnya jumlah narapidana merupakan alternatif yang patut untuk dipertimbangkan. Indonesia telah

${ }^{1}$ https://www.cnnindonesia.com/nasional/20200416152520-20-494204/yasonna-pembebasan-napi-saatcorona-rekomendasi-pbb, diakses Jumat, 17 Meret 2021

${ }^{2}$ https://www.liputan6.com/news/read/4264311/39876-napi-asimilasi-dibebaskan-di-tengah-wabahcorona-hingga-27-mei-2020, diakses 27 Mei 2021 
memiliki mekanisme diversi dan keadilan restoratif (restorative justice) yang dapat diintensifkan penggunaannya dengan tetap memperhatikan tingkat keseriusan kasus maupun berat ringan ancaman pidananya dalam peraturan perundang-undangan. Penggunaan mekanisme keadilan restoratif ini telah banyak mendapat perhatian dari berbagai kalangan, dan pemerintah telah mengakomodasi pemberlakuannya dalam peraturan perundang-undangan di Indonesia, antara lain dalam Undang-undang Nomor 11 Tahun 2012 tentang Sistem Peradilan Pidana Anak (SPPA).

Zainal Abidin menyatakan bahwa keadilan restoratif telah ditempatkan dalam konteks menjawab permasalahan yang bersifat subtantif dan praktis. Secara subtantif, peradigma tentang korban kejahatan, pendekatan yang berorientasi pada pemulihan korban dan membuka ruang partisipasi masyarakat. Secara praktis, mengurangi beban penjara - overkapasitas yang berdampak pada sulitnya memperbaiki perlakukan para pelaku sesuai dengan standar. Namun, keadilan restoratif belum ditempatkan dalam konteks yang lebih besar - sebagai jalan untuk me 'restore' kondisi sebagai dampak dari konflik yang terjadi dan mengatasi 'social injustice', sebagai salah satu masalah kontemporer yang dihadapi Indonesia. ${ }^{3}$ Dalam konteks kekerasan terhadap perempuan, baik anak maupun dalam rumah tangga, kerap pendekatan ini digunakan oleh penyidik.

Dalam Handbook on Restorative Justice Programmes yang diterbitkan oleh PBB disebutkan bahwa, "Restorative justice is an approach to problem solving that, in its various forms, involves the victim, the offender, their social networks, justice agencies and the community." "Hubungan dengan penegakan hukum pidana, maka restorative justice merupakan suatu pendekatan dalam memecahkan masalah pidana yang melibatkan korban, pelaku, serta elemen-elemen masyarakat demi terciptanya suatu keadilan. ${ }^{5}$ Restorative Justice kemudian mendapat tempat yang lebih luas ketika Direktur Jenderal Peradilan Umum Mahkamah Agung RI menerbitkan Surat Keputusan Nomor 1691 Tahun 2020 tentang Pemberlakuan Pedoman Penerapan Keadilan Restoratif.

3 Zainal Abidin, Peluang dan Tantangan Restorative Justice [RJ] di Indonesia, Seminar Nasional "Mendorong Restorative Justice dalam Pembaruan Hukum Pidana di Indonesia: Menggali Pemikiran Prof. Mardjono Reksodiputro, S.H., M.A. dalam Pembaruan Hukum Pidana Indonesia" 17 Juli 2019

4 United Nations, 2006, Handbook on Restorative Justice Programmes, New York: United Nations Publication, hal. 6

${ }^{5}$ Badan Pembinaan Hukum Nasional Kementerian Hukum Dan HAM RI Tahun 2013 Pengkajian Hukum Tentang Penerapan Restorative Justice Dalam Penyelesaian Tindak Pidana Yang Dilakukan Oleh Anak-Anak, Jakarta, 2013, hal 6 
Hal ini lebih diperkuat ketika dalam konteks pandemi Covid-19, Komnas HAM meminta kepolisian agar menggunakan pendekatan restorative justice sebagai alternatif penyelesaian tindak pidana dalam masa pandemi COVID-19 guna memberikan keadilan dan keseimbangan bagi pelaku tindak pidana maupun korban.

Penelitian ini adalah penelitian yuridis empiris, yaitu penelitian hukum mengenai pemberlakuan ketentuan hukum normatif secara konkrit pada suatu peristiwa hukum tertentu yang terjadi dalam masyarakat. ${ }^{6}$ Penelitian dilakukan dalam wilayah hukum Polres Kepulauan Aru, Maluku Barat Daya dan Polresta Pulau Ambon dan Pulau-pulau Lease. Dalam penelitian yuridis empiris, jenis data yang dibutuhkan adalah data primer yang diperoleh langsung dari masyarakat dan data sekunder yang diperoleh dari bahan pustaka. Data primer diperoleh secara langsung berupa keterangan dan pendapat responden dan kenyataan-kenyataan yang ada di masyarakat melalui wawancara dan observasi. ${ }^{7}$ Dengan demikian, dalam penelitian ini, data primer diperoleh dari aparat penegak hukum yang melakukan penanganan terhadap kasus kekerasan terhadap perempuan, baik pada tingkat penyidikan maupun penuntutan. Sedangkan data sekunder yang diperoleh dari studi kepustakaan terdiri dari bahan hukum primer, yakni peraturan perundangan yang berkaitan dengan penegakan hukum tindak pidana korupsi, antara lain Undang-undang Nomor 11 Tahun 2012, Undang-undang Nomor 23 Tahun 2004, bahan hukum sekunder yaitu bahan hukum yang membantu dalam menganalisa serta memahami permasalahan, yang diperoleh melalui buku-buku, hasil penelitian dan lain-lainnya, bahan hukum tertier berupa kamus hukum dan informasi ilmiah lainnya melalui website dan sebagainya.Data primer diperoleh melalui wawancara dan studi lapangan penerapan restorative justice dalam wilayah hukum Polres Kepulauan Aru, Polres Maluku Barat Daya, dan Polresta Pulau Ambon dan Pulau-pulau Lease, yang kemudian dianalisis secara kualitatif dengan mendiskripsikan data dan fakta yang dihasilkan. Data dinalisis secara induktif, yakni berdasarkan fakta yang bersifat umum dilanjutkan dengan penarikan kesimpulan secara khusus dan mengajukan saran-saran.

\footnotetext{
${ }^{6}$ Abdul K. Muhammad, 2004, Hukum dan Penelitian Hukum, Citra Aditya Bakti, Bandung, hal 154

${ }^{7}$ Soerjono Soekanto, 1986, Pengantar Penelitian Hukum, Universitas Indonesia, Jakarta, hal11
} 


\section{Pembahasan}

\section{Perkembangan Restorative Justice}

Model dan mekanisme sistem peradilan pidana mengalami perubahan dari waktu kewaktu. Perkembangan ilmu pengetahuan dan teknologi turut berkontribusi terhadap pembaharuan sistem peradilan pidana. Salah satunya adalah pendekatan Restorative Justice atau keadilan restoratif. Pendekatan ini diasumsikan sebagai pergeseran paling mutakhir dari berbagai model dan mekanisme yang bekerja dalam sistem peradilan pidana dalam menangani perkara pidana saat ini. PBB melalui Basic Principles on the Use of Restorative Justice Programmes in Criminal Matters Tahun 2002, ${ }^{8}$ menilai bahwa keadilan restoratif adalah pendekatan yang dapat dipakai dalam sistem peradilan pidana yang rasional. Ini sejalan dengan pandangan G.P.Hoefnagels yang menyatakan bahwa politik kriminal harus rasional (a rational total of the responses to crime). Pendekatan keadilan restoratif merupakan suatu paradigma yang dapat dipakai sebagai bingkai dari strategi penanganan perkara pidana yang bertujuan menjawab ketidakpuasan atas bekerjanya sistem peradilan pidana yang ada saat ini. ${ }^{9}$

Marian Liebmann mengemukakan bahwa secara sederhana, keadilan restoratif bertujuan untuk mengembalikan kesejahteraan korban, pelaku dan masyarakat yang rusak oleh kejahatan, dan untuk mencegah kejahatan lebih lanjut. ${ }^{10}$ Braithwaite mengemukakan, ${ }^{11}$

"On (the procedural) view, restorative justice is a process that brings together all stakeholder affected by some harm. That has been done... These stakehorlders meet in a circle to discuss how they have been affected by the harm and come to some agreement as to what should be done to right any wrongs suffered. ...Restorative justice is about healing (restorative) than hurting.

Sedangkan Howard Zehr merumuskan, Viewed through a restorative justice lens, "crime is a violation of people and relationships. It creates obligations to make things right. Justice involves the victim, the offender, and the community in a search for solutions which promote repair, reconciliation, and reassurance." 12

\footnotetext{
${ }^{8}$ United Nations Commission on Crime Prevention and Criminal Justice, Basic Principles on the Use of Restorative Justice Programmes in Criminal Matters. Vienna: UN. 2002

${ }^{9}$ Eva Achjani Zulfa, 2011, Pergeseran Paradigma Pemidanaan, Lubuk Agung, Bandung, hal.1

${ }^{10}$ Marian Liebmann, 2007 Restorative Justice, How it Works, Jessica Kingsley Publisher, London and Philadelphia, 2007, hal 25

${ }^{11}$ Braithwaite, J. 2001 Shame Management Through Reintegration, Melbourne: Cambridge University Press, 2001, hal 17

${ }^{12}$ H. Zehr and B. Toews (eds), 2002, Critical Issues in Restorative Justice, Monsey, NY: Criminal Justice Press, hal 57
} 
Pendapat-pendapat tersebut secara tegas menggambarkan bahwa persoalan tindak pidana bukan hanya melibatkan orang perorangan. Tindak pidana menimbulkan luka yang berpengaruh terhadap korban, masyarakat, bahkan pelaku itu sendiri, dan fungsi dari proses peradilan pidana bukanlah menghukum melainkan mendapatkan solusi dengan melibatkan semua pihak yang terlibat. Keadilan restoratif adalah suatu proses dimana semua pihak yang terlibat dalam suatu tindak pidana tertentu bersama-sama memecahkan masalah bagaimana menangani akibat di masa yang akan datang. Tindak pidana menciptakan kewajiban untuk membuat segala sesuatunya menjadi pulih dengan melibatkan korban, pelaku, dan masyarakat dalam mencari solusi untuk memperbaiki.

Dari perkembangan keadilan restoratif tersebut, terlihat bahwa pendekatan ini sudah digunakan bukan saja terhadap kasus yang melibatkan anak atau remaja, melainkan berkembang juga untuk kasus orang dewasa, termasuk di dalamnya kasus kekerasan dalam rumah tangga. Keadilan restoratif sendiri mengandung prinsip-prinsip: ${ }^{13}$

a. Membuat pelanggar bertanggung jawab untuk memperbaiki kerugian yang ditimbulkan oleh kesalahannya;

b. Memberikan kesempatan kepada pelanggar untuk membuktikan kapasitas dan kualitasnya disamping mengatasi rasa bersalah secara konstruktif;

c. Melibatkan para korban, orang tua, keluarga besar, sekolah, teman sebaya;

d. Menciptakan forum untuk bekerja sama dalam menyelesaikan masalah tersebut; dan

e. Menetapkan hubungan langsung dan nyata antara kesalahan dengan reaksi sosial yang formal.

Dalam beberapa tahun terakhir, di Australia, Kanada, dan Selandia Baru, para sarjana dan praktisi kekerasan keluarga mulai mengeksplorasi kemungkinan keadilan restoratif dalam berurusan dengan kekerasan rumah tangga. ${ }^{14}$ Bukti empiris dari pendukung korban Australia seperi Curtis-Fawley dan Daly, ${ }^{15}$ menunjukkan bahwa banyak pihak juga melihat aspek positif terhadap proses peradilan restoratif. Misalnya, pendapat yang menegaskan pentingnya forum

13 Marilyn Fernandez, 2010, Restorative Justice for Domestic Violence Victims, An Integrated Approach to Their Hunger for Healing, Lexington Books, United Kingdom, 2010, hal. 151.

${ }^{14}$ Stephanie Coward, "Restorative Justice in Cases of Domestic and Sexual Violence: Healing Justice." Abuse Info and Resources. 2002, accesed 29 Oktober 2019 www.hotpeachpages.net/canada/air/rj_domestic violence.html.

15 Curtis-Fawley, Sarah, and Kathleen Daly. 2005. "Gendered Violence and Restorative Justice: The Views of Victim Advocates." Violence Against Women 11(5): 603 
keadilan yang restoratif, yang menawarkan korban untuk mengekspresikan suara dan keprihatinan mereka. Mereka juga menghargai informalitas proses sebagai hal yang bermanfaat bagi korban, terutama yang ingin melanjutkan hubungan mereka dengan pelaku. Untuk para pendukung, fitur lain yang menarik adalah kesempatan bahwa keadilan restoratif menawarkan pelanggar mengakui bertanggung jawab dan untuk mengasumsikan pertanggungjawaban atas kejahatannya.

Berkaitan dengan kekerasan terhadap perempuan, terdapat empat prinsip umum dalam keadilan restoratif, yaitu, ${ }^{16}$

a. memulihkan korban kejahatan

b. mencegah individu pelanggar mengulangi tindakannya

c. mendorong peran masyarakat dalam menanggapi kejahatan

d. menekankan konteks sosial di mana terdapat kejahatan.

Zehr terus mengelaborasi kolaboratif, inklusif, dan sifat holistik dari proses restoratif, yang hasilnya disepakati bersama, bukan dipaksakan. ${ }^{18} \mathrm{Hal}$ ini bertentangan dengan model keadilan retributif pidana. Kebijakan peradilan pidana difokuskan pada menyeimbangkan hak-hak pelanggar dan kepentingan kekuasaan pemerintah dalam menjaga ketertiban umum dan keamanan

Berkenan dengan itu, John Braithwaite mengemukakan bahwa "Restorative justice means restoring victims, a more victim-centered criminal justice system, as well as restoring offenders and restoring community.' Sedangkan Howard Zehr menamakan Restorative Justice as "victim-oriented approach.", 19

\section{Kekerasan terhadap Perempuan}

Menurut Deklarasi Eliminasi Kekerasan Terhadap Perempuan (Declaration on the Elimination of Violence Against Women/DEVAW, kekerasan terhadap perempuan adalah setiap tindakan kekerasan berbasis gender yang mengakibatkan, atau kemungkinan mengakibatkan, kerusakan fisik atau seksual atau penderitaan atau penderitaan bagi perempuan, termasuk

${ }^{16}$ Loretta Frederick and Kristine Lizda, 2010, The Role of Restorative Justice in the Battered Women's Movement, in Restorative Justice And Violence Against Women edited by James Ptacek, Oxford University Press, hal 40 
ancaman dari tindakan tersebut, pemaksaan atau perampasan kebebasan secara sewenangwenang, baik yang terjadi di publik maupun dalam kehidupan pribadi.

Kekerasan terhadap perempuan harus dipahami mencakup, tetapi tidak terbatas pada, hal-hal berikut:

(a) Kekerasan fisik, seksual dan psikologis yang terjadi dalam keluarga, termasuk pemukulan, pelecehan seksual terhadap anak-anak perempuan dalam rumah tangga, kekerasan terkait mahar, perkosaan dalam perkawinan , mutilasi alat kelamin wanita dan praktik-praktik tradisional lainnya yang berbahaya bagi wanita, kekerasan non-pasangan dan kekerasan terkait eksploitasi;

(b) Kekerasan fisik, seksual dan psikologis yang terjadi dalam masyarakat umum, termasuk pemerkosaan, termasuk pelecehan seksual, pelecehan seksual dan intimidasi di tempat kerja, di lembaga pendidikan dan di tempat lain, perdagangan perempuan dan prostitusi paksa;

(c) Kekerasan fisik, seksual dan psikologis yang dilakukan atau dimaafkan oleh Negara, di mana pun itu terjadi.

Kekerasan terhadap perempuan adalah setiap perbuatan berdasarkan perbedaan kelamin yang berakibat atau mungkin berakibat kesengsaraan dan penderitaan perempuan secara fisik, seksual atau psikologis, termasuk ancaman tertentu, pemaksaan atau perampasan kemerdekaan secara sewenang-wenang baik yang terjadi di depan umum atau dalam kehidupan pribadi. ${ }^{17}$ Berdasarkan pasal 1 dan pasal 2 deklarasi PBB tersebut, maka kekerasan terhadap perempuan dapat digolongkan ke dalam beberapa bentuk, yaitu kekerasan fisik, seksual, psikologis, ekonomi dan perampasan kemerdekaan.

a. Kekerasan fisik adalah setiap perbuatan yang menyebabkan rasa sakit, cedera, luka atau cacat pada tubuh seseorang dan atau menyebabkan kematian.

b. Kekerasan seksual adalah tiap-tiap perbuatan yang mencakup pelecehan seksual sampai kepada memaksa seseorang untuk melakukan hubungan seksual tanpa persetujuan korban atau di saat korban tidak menghendaki; dan atau melakukan hubungan seksual dengan cara-cara tidak wajar atau tidak disukai korban; dan atau menjauhkan (mengisolasi) dari kebutuhan seksualnya.

${ }^{17}$ Moerti Hadiati Soeroso, 2010, Kekerasan dalam Rumah Tangga dalam Perspektif Yuridis- Viktimologis, Sinar Grafika Jakarta. 
c. Kekerasan psikologis adalah setiap perbuatan dan ucapan yang mengakibatkan ketakutan, hilangnya rasa percaya diri, hilangnya kemampuan untuk bertindak dan rasa tidak berdaya pada seseorang.

d. Kekerasan ekonomi adalah tiap-tiap perbuatan yang membatasi seseorang untuk bekerja di dalam dan di luar rumah yang menghasilkan uang dan barang, membiarkan korban bekerja untuk dieksploitasi dan menelantarkan anggota keluarga.

e. Perampasan kemerdekaan secara sewenang-wenang adalah semua perbuatan yang menyebabkan terisolirnya seseorang dari lingkungan sosialnya.

Menurut Mansoer Fakih kekerasan terhadap perempuan antara lain pemerkosaan, pelecehan seksual, kekerasan phisik dan psikis. ${ }^{18}$ Feminis mengklasifikasikan kekerasan dalam rumah tangga pada empat kategori; Pertama: tindakan fisik dan psikis.Kedua: Pemaksaan terhadap pasangan (isteri) yang enggan melakukan hubungan, yang biasa diistilahkan dengan sexual abuse.Ketiga: melarang pasangan untuk melakukan silaturahmi dengan teman-temannya, keluarganya dan tidak mengizinkan untuk aktifdalam kegiatan kemasyarakatan. Ini dikenal dengan social abuse.Keempat: membatasi dan mengontrol keuangan atau belanja isteri, yang distilahkan economic abuse. ${ }^{19}$

Diaturnya kekerasan terhadap perempuan dalam deklarasi internasional menandakan bahwa kekerasan terhadap perempuan merupakan isu yang global, yang terjadi di berbagai belahan dunia.

Di Indonesia, Komisi Nasional Anti Kekerasan Terhadap Perempuan, dalam Catatan Tahunan memberikan gambaran angka kekerasan terhadap perempuan meningkat dari tahun ke tahun. Bahkan Nurani Perempuan Women's Crisis Center (WCC) menemukan beragam kasus kekerasan terhadap perempuan di masa pandemi Covid-19. Kekerasan yang terjadi di ranah domestik berupa penelantaran dan kekerasan psikologis. Hal ini terjadi karena pada masa pandemi Covid-19 perempuan lebih banyak melakukan pekerjaan di rumah dan beban kerja semakin tinggi. ${ }^{20}$

\footnotetext{
${ }^{18}$ Mansoer Fakih, 1996, Analisis Gender dan Transformasi Sosial, Pustaka Pelajar, Yogyakarta, hal 13

${ }^{19}$ Chaney, Daniel J and Claire m. Renzetti, 2005, Sosial Problem, Buston:allyn and bacon, hal 24

20 Nurani Perempuan Women's Crisis Center (NPWCC), Kamis 18 Juli 2020
} 


\section{Penerapan Konsep Restorative Justice Dalam Penanganan Kasus Kekerasan Terhadap Perempuan Di Maluku Dalam Masa Pandemic Covid-19}

Praktek penyelesaian perkara pidana melalui jalur "musyawarah" antar pelaku dan korban serta masyarakat yang terlibat di dalamnya, merupakan suatu kenyataan yang ada dalam masyarakat Indonesia. Mekanisme penyelesaian ini dalam prakteknya terselenggara dengan atau tanpa melibatkan penegak hukum. Secara praktis, perdamaian sebagai hasil akhir dari musyawarah menjadi kunci penutup permasalahan yang terjadi seolah mendapatkan pembenaran berdasarkan hukum yang hidup dalam masyarakat. Akan tetapi hal ini sesungguhnya memiliki implikasi secara teoretis maupun yuridis. Di sejumlah negara hal ini dijembatani melalui kebijakan baik dalam bentuk program pemerintah atau dalam regulasinya. Kebijakan dan program ini dibuat berdasarkan filosofi pemidanaan tradisional yang membingkainya yang dikenal sebagai keadilan restoratif. Keadilan restoratif merupakan suatu filosofi pemidanaan tradisional yang dapat dipakai sebagai pendekatan dalam penanganan dan penyelesaian perkara pidana yang terjadi dalam masyarakat. ${ }^{21}$

Kegagalan penjara mengatasi masalah kejahatan dapat dilihat dari kegagalan fungsinya untuk menghilangkan kemungkinan pelaku melakukan kejahatan lebih jauh karena terbukti banyakn jenis kejahatan yang dapat dilakukan di dan dari dalam penjara. Selain itu unsur kesakitan dan ketakutan untuk menjerakan yang menjadi dasar filosofi penjara terbukti tidak efektif menurunkan angka kejahatan bahkan justru menyumbang pada angka residivisme. Sementara itu, sistem penjara terbukti berbiaya besar, baik secara finansial maupun biaya sumber daya manusia. ${ }^{22}$

Dengan demikian, keadilan yang restoratif adalah apabila proses pencapaiannya mendorong pelaku untuk bertanggung jawab atas perbuatannya, memberikan kesempatan bagi pelaku untuk mengganti kesalahan yang dilakukannya dengan berbuat kebaikan bagi si korban, memberikan kesempatan bagi korban untuk ikut serta dalam proses, memberikan kesempatan bagi pelaku untuk dapat mempertahankan hubungan dengan keluarga, memenuhi kebutuhan mereka yang dirugikan oleh tindak pidana dan memberikan kesempatan bagi rekonsiliasi dan penyembuhan masyarakat yang dirugikan.

\footnotetext{
${ }^{21}$ Latumaerissa, D. (2020). Kajian Kriminologi Terhadap Kekerasan Yang Dilakukan Oleh Perempuan di Kota Ambon. JURNAL BELO, 5(2), 57-73. https://doi.org/10.30598/belovol5issue2page57-73

22 Fadillah, A. (2019). Perlindungan Hukum Terhadap Anak Yang Menjadi Korban Aksi Perundungan. JURNAL BELO, 5(1), 86-100. https://doi.org/10.30598/belovol5issue1 page86-100
} 
Restorative justice juga merupakan salah satu jalan keluar untur menghindari overcapacity di dalam lembaga pemasyarakatan, dan ini telah diterapkan di beberapa negara. Melalui diversi, suatu kasus dikeluarkan dari sistem peradilan pidana, baik pada tahapan penyidikan, penuntutan bahkan pemeriksaan perkara, dan diselesaikan dengan menggunakan mekanisme restorative justice.

Hasil penelitian menunjukkan bahwa proses penyelesaian kasus kekerasan terhadap perempuan di Maluku dalam lingkungan Polres cenderung dilakukan melalui mekanisme restorative justice, meskipun dalam kasus tertentu, tetap dilanjutkan ke tahap penuntutan (P21). Terdapat indikasi bahwa dalam kasus-kasus kekerasan terhadap perempuan, tidak selamanya diselesaikan dengan menggunakan mekanisme restorative justice, baik sebelum masa pandemi Covid maupun dalam masa pandemi Covid. Untuk kasus-kasus KDRT terutama kekerasan terhadap isteri lebih banyak dilakukan restorasi dengan alasan memberikan perlindungan kepada anak, meskipun realitasnya ada kasus yang dilanjutkan ke tahap penyerahan perkara ke penuntut umum (P21). Kasus-kasus penganiayaan ada yang direstorasi, namun sebagian tetap dilanjutkan. Kasus-kasus pencabulan anak lebih banyak yang tetap dilanjutkan, meskipun ada yang diselesaikan dengan mekanisme restorative justice. Salah satu kasus yang dihentikan penyidikannya di Polres Kepulauan Aru dengan alasan telah dilakukan penyelesaian menurut hukum adat yang difasilitasi oleh penyidik adalah kasus Pencabulan yang dialami oleh NN umur 15 tahun. Pelaku adalah DK berusia 21 tahun. Pelaku melakukan pencabulan terhadap korban dengan pemaksaan hubungan intim dan menggigit payudara korban sehingga luka dan bernanah. Korban/keluarga korban melakukan pengaduan ke Polres Kepulauan Aru dengan nomor register perkara nomor : LP/01/V/2017/Reskrim. Tetapi kemudian pihak korban dan pelaku melakukan penyelesaian menurut hukum adat Datalar Dai Kupal Tit (Duduk di atas tikar untuk menyelesaikan adat), menurut adat desa Kalar-kalar, oleh karena pelaku dan korban sama-sama orang asli Kepulauan Aru. Proses ini difasilitasi oleh penyidik bersama Dewan Adat Desa Kalarkalar, dan menghasilkan kesepakatan pihak keluarga tersangka membayar sebesar Rp. 4.500.000 kepada pihak keluarga korban disertai permintaan maaf kepada korban dan keluarganya. Berdasarkan hal tersebut, maka pihak korban menyampaikan permintaan kepada pihak penyidik untuk tidak melanjutkan kasus tersebut karena telah diselesaikan menurut hukum adat. Penyidik kemudian mengeluarkan SP3 dengan nomor SPPP/07/08/2017/Reskrim. 
Sedangkan data kekerasan terhadap perempuan, terutama kekerasan dalam rumah tangga di Maluku Barat Daya menggambarkan bahwa untuk kasus kekerasan terhadap perempuan, terutama kekerasan dalam rumah tangga, maka proses penyelesaiannya dilakukan melalui mekanisme mediasi penal sesuai dengan hukum adat masyararakat Maluku Barat Daya. Penyidik memfasilitasi proses mediasi yang dilakukan oleh tua-tua adat, keluarga dan para pihak. Mediasi penal merupakan salah satu bentuk dalam proses restorative justice.

Mengingat bahwa kekerasan dalam rumah tangga merupakan hal yang kompleks, yang berbeda dengan kekerasan lainnya, maka dalam proses penanganan melalui sistem peradilan pidana, hendaknya dipertimbangkan penggunaan mekanisme tertentu, yang dapat menjawab kebutuhan para pihak yang terlibat dalam kasus KDRT tersebut. Pada bagian lain, realitas bahwa banyak kasus KDRT yang dilaporkan tidak dapat diteruskan karena korban yang melapor mencabut kembali laporannya dengan berbagai latar belakang penyebabnya, mengindikasikan diperlukannya mekanisme penyelesaian kasus KDRT yang spesifik.

Model restorative justice dalam berbagai bentuk, terutama mediasi penal dapat diterapkan untuk melengkapi mekanisme sistem peradilan pidana, bahkan dapat merupakan pilihan sebagai sarana pengalihan/diversi. Setiap komponen dalam sistem peradilan pidana dapat menerapkan hal ini. Pada tingkat penyidikan misalnya, polisi melalui kewenangan diskresi (power of discretion) berdasarkan Pasal 18 ayat 1 Undang-undang Nomor 2 Tahun 2002 tentang Kepolisian Negara RI, dapat mengambil tindakan berdasarkan pertimbangan dan keyakinannya untuk tidak memproses kasus KDRT tertentu, dan kemudian menyelesaikannya melalui mekanisme di luar pengadilan. ${ }^{23}$ Mekanisme diversi, yakni suatu pengalihan bentuk penyelesaian dari yang bersifat proses pidana formal ke alternatif penyelesaian dalam bentuk lain dapat menjadi pedoman bagi polisi berdasarkan Pasal 16 ayat 1 huruf L UU Polri. Kewenangan diversi ini dapat diaplikasikan apabila jalan hukum yang disediakan untuk menghadapi suatu kasus malah menjadi macet, tidak efisien, boros dan atau kurang bermanfaat.

Meskipun kelihatannya seperti melakukan tindakan yang tidak berdasarkan hukum, namun tindakan tersebut justru menjunjung tinggi tujuan hukum itu sendiri, yaitu perlindungan masyarakat. Menurut Satjipto Rahardjo, hukum itu hanya dapat menuntut kehidupan bersama secara umum. Sebab begitu ia mengatur secara rinci, dengan memberikan skenario langkah-

23 Elsa R.M. Toule, 2011, Penanggulangan Kekerasan Dalam Rumah Tangga (Suatu Pendekatan Yang Terintegral) Unpad Press, Bandung. 
langkah secara lengkap, maka pada waktu itu pula, kehidupan akan macet. Oleh karena itu, sesungguhnya, diskresi merupakan kelengkapan dari pengaturan hukum itu sendiri. Dengan demikian, diskresi itu sesungguhnya suatu keputusan/ tindakan kepolisian yang dengan sadar tidak melakukan kewajiban/tugasnya selaku penegak hukum berdasarkan alasan-alasan yang dapat dipertanggungjawabkan berdasarkan hukum itu sendiri. ${ }^{24}$

Mekanisme demikian menjadi penting karena meskipun istri sebagai korban KDRT telah melaporkan suaminya ke polisi, tetapi tujuan yang diinginkannya adalah hanya memberi pelajaran bagi suaminya, dan bukan untuk bercerai. Perempuan korban KDRT selalu diperhadapkan pada dilemma: melaporkan suami dan berakibatkan perceraian, ataukah tetap menerima kekerasan yang dilakukan oleh suami agar tetap berada dalam ikatan perkawinan. Dengan demikian, melalui model keadilan restoratif, kepentingan perempuan korban KDRT dapat terakomodasi. Gambaran dari kasus tersebut memperlihatkan begitu spesifiknya kasus KDRT, yang tentunya tidak dapat terselesaikan dengan mekanisme peradilan pidana yang biasa. Namun pada sisi lain, penyelesaian yang demikian, belum memiliki dasar hukumnya. Proses penyelesaian di luar pengadilan, hanya baru diatur dalam Pasal 145 Rancangan KUHP Tahun 2006.

\section{Faktor Yang Mempengaruhi Penerapan Konsep Restotative Justice Terhadap Kasus Kekerasan Terhadap Perempuan}

Bentuk restorative justice yang paling dominan diterapkan di Indonesia adalah Mediasi penal, yang merupakan alternatif penyelesaian perkara pidana di luar jalur penal. Dalam penyelesaian perkara pidana jika menempuh jalur penal biasanya selalu adanya penjatuhan pidana oleh hakim terhadap pelaku, hal ini secara filosofis kadang-kadang tidak memuaskan semua pihak, oleh karena itu perlu adanya pemikiran penyelesaian perkara pidana melalui jalur ADR (Alternative Dispute Resolution) dengan maksud agar dapat menyelesaikan konflik yang terjadi antara pelaku dengan korban. Pendekatan melalui jalur ADR, pada mulanya termasuk dalam wilayah hukum keperdataan, namun dalam perkembangannya dapat pula digunakan oleh hukum pidana, hal ini sebagaimana diatur dalam dokumen penunjang Kongres PBB ke-6 Tahun 1995. Dokumen A/CO NF.169/6 menjelaskan dalam perkara-perkara pidana yang mengandung unsur fraud dan white-collar crime atau apabila terdakwanya korporasi, maka pengadilan

\footnotetext{
${ }^{24}$ Satjipto Rahardjo, 1980, Hukum dan Masyarakat, Angkasa, Bandung, hal 20
} 
seharusnya tidak menjatuhkan pidana, tetapi mencapai suatu hasil yang bermanfaat bagi kepentingan masyarakat secara menyeluruh dan mengurangi kemungkinan terjadinya pengulangan.

Menurut Muladi, model konsensus yang dianggap menimbulkan konflik baru harus diganti dengan model asensus, karena dialog antara yang berselisih untuk menyelesaikan masalahnya, adalah langkah yang sangat positif. Dengan konsep ini muncul istilah ADR yang dalam hal-hal tertentu menurut Muladi lebih memenuhi tuntutan keadilan dan efesien. ADR ini merupakan bagian dari konsep restorative justice yang menempatkan peradilan pada posisi mediator. $^{25}$

Dalam United Nations Office for Drug Control and Crime Prevention, dinyatakan bahwa restorative justice merupakan sebuah istilah baru terhadap konsep lama. Pendekatan restorative justice telah digunakan dalam memecahkan masalah konflik antara para pihak dan memulihkan perdamaian di masyarakat. Karena pendekatan-pendekatan retributive atau rehabilitative terhadap kejahatan dalam tahun-tahun terakhir ini dianggap sudah tidak memuaskan lagi. Oleh karenanya menyebabkan dorongan untuk beralih kepada pendekatan restorative justice. Kerangka pendekatan restorative justice melibatkan pelaku, korban dan masyarakat dalam upaya untuk menciptakan keseimbangan, antara pelaku dan korban.4 Juga dapat dilihat dalam Dokumen A/CONF.187/8 yang disampaikan pada kongres PBB ke-10 tentang the Prevention of crime and the Treatment of Offenders yang diselenggarakan di Vienna, 10 - 17 April 2000, yang mana pada bagian Basic principles of justice for offenders and victims, antara dicantumkan mengenai the alternative of restorative justice. Menurut dokumen, restorative justice dipandang sebagai sebuah model alternatif dalam peradilan pidana. Di mana semua pihak ambil bagian untuk menyelesaikan permasalahan tertentu secara bersama-sama bagaimana menghadapi akibat dari permasalahan itu serta implikasinya bagi yang akan datang. Dalam model ini, penekanannya terletak pada perbaikan (reparation) dan pencegahan (prevention) ketimbang menjatuhkan pidana. Restorative justice ini dan bentuk-bentuk lainnya dari penyelesaiain perselisihan (dispute resolusion) baik formal maupun semi formal, mencerminkan kecenderungan masa kini dari faham individualisme dan mengurangi fungsi dari negara. Pada awal penyelesaian perkara diluar

${ }^{25}$ Leasa, E. (2019). Kekuatan Keterangan Saksi Sebagai Alat Bukti Pada Perkara Kekerasan Dalam Rumah Tangga. JURNAL BELO, 4(2), 188-203. https://doi.org/10.30598/belovol4issue2page188-203 
pengadilan dikenal dengan istilah ADR yang merupakan bagian dari restorative justice yang merupakan kecenderungan baru dalam upaya menyelesaikan konflik antara pelaku dan korban atau para pihak yang berselisih. Kecenderungan orang menyelesaikan konflik dengan ADR dikarenakan banyak terjadinya penyelesaian kasus melalui peradilan tidak mencapai sasaran dan berkeadilan.

Pemikiran yang mengedepankan penyelesaian perkara pidana di luar pengadilan sebagaimana yang terjadi di Amerika, lambat laun dapat berimbas ke Indonesia mengingat opini dan pandangan para praktisi hukum dan akademisi terhadap proses peradilan pidana sangatlah mengecewakan dan menyedihkan bagi para pencari keadilan. Untuk itu fenomena penyelesaian di luar pengadilan perlu dicermati para penegak hukum Indonesia yang saat sekarang berada dalam posisi yang sangat nadir dan mencemaskan bagi penegakkan hukum secara normatif. Hanya saja perlu juga dipikirkan bahwa penyelesaian perkara di luar pengadilan jangan menimbulkan persoalan-persoalan hukum baru, terutama terhadap lembaga peradilan yang tidak mempunyai fungsi sama sekali. Dalam konteks demikian jika dimungkinkan adanya jalur penyelesaian hukum di luar pengadilan, hanya merupakan penyeimbang dari kebijakan penal dan merupakan alternatif kebijakan non penal. Untuk itu perlu adanya terobosan dalam sistem peradilan pidana untuk mengupayakan adanya mediasi penal.

Di Maluku, meskipun banyak keragaman yang dimiliki, namun orang Maluku masih bisa merangkai dan merangkul keberadaannya dalam sebuah kesadaran kolektif dan konsep diri sebagai orang basudara. Orang basudara merangkul dan menyatukan perbedaan dan membentuk diri sebagai sebuah masyarakat yang bersatu meskipun berbeda. Orang basudara adalah habitat asli orang Maluku, karena setiap masyarakat Maluku adalah pendukung komunitas orang basudara. Mereka mengoperasionalkan hakikat hidupnya itu dalam budaya hidop orang basudara sebagai sebuah karakter asli. Spirit hidop orang basudara itu nampak secara spesifik pada berbagai bentuk kekerabatan adat dan tradisi adat di wilayah kepulauan Maluku. Falsafah budaya Pela Gandong di Maluku Tengah sebagai satu sub zona makro kebudayaan Maluku, falsafah budaya Ain Ni Ain (budaya satu punya satu) di Kepulauan Kei Maluku Tenggara, falsafah budaya Kai-Wai (budaya adik kakak) di Pulau Buru, falsafah Budaya Ursia-Urlim (kekerabatan adat kelompok dari dua leluhur bersaudara Ursia-Urlima di kepulauan Aru, falsafah budaya Duan Lolat (kekerabatan kelompok pemberi anak dara dan 
kelompok penerima anak dara) di Kepulauan Tanimbar, serta budaya Sioli Lieta Inanara (budaya hidup baik-baik bapa, mama, basudara laki-laki dan perempuan) di Maluku Barat Daya.

Budaya orang Maluku yang hidup sebagai orang basudara ini merupakan kearifan lokal di berbagai wilayah Maluku dapat menjadi pilihan utama, yang perlu digali dan dikembangkan dalam menyelesaikan persoalan-persoalan hukum, diantaranya kekerasan dalam rumah tangga, karena keadilan restoratif sebenarnya berakar dari kearifan lokal masyarakat Indonesia yang memiliki budaya musyawarah untuk mufakat, baik melalui sidang-sidang adat maupun dalam acara "kumpul sudara."26

Nilai keadilan restoratif di Maluku Tengah, ditemui dalam budaya Pela yang merupakan bentuk ikatan persaudaraan dibangun oleh satu negeri dengan satu atau beberapa negeri lain dengan bentuk antara lain Pela Gandong, Pela Tampa Sirih, yang memiliki beberapa aturan dasar yang harus dipatuhi oleh warga suatu negeri yang terikat dalam hubungan pela. Ikatan pela ini kemudian menginspirasikan masyarakat Maluku untuk menganggap orang lain sebagai saudara, sehingga ketika terjadi konflik, maka spirit Pela ini akan menjadi panutan dalam menyelesaikannya.

Faktor ini yang sangat mendukung proses penyelesaian kasus-kasus termasuk kasus kekerasan dalam rumah tangga melalui restorative justice. Meskipun demikian, tidak semua kasus dapat diselesaikan dengan mekanisme ini, mengingat dalam kasus tertentu, terutama berkaitan dengan perempuan (anak), yang menjadi korban, maka penyidik cenderung untuk tetap melakukan proses sampai ketahap penyerahan tersangka dan berkas ke penuntut umum (P21). Hal mana sejalan dengan konsep perlindungan anak, yaitu kepentingan terbaik untuk anak. Salah satu contoh terlihat dari keputusan penyidik dalam kasus pelecehan seksual terhadap anak di Wilayah Hukum Polres Kepulauan Aru, dengan pengaduan nomor:LP/74/VI/2020/Mal/Res Aru dengan korban NWIP 15 tahun, yang mengalami pencabulan oleh tersangka JU dan DU. Keluarga korban dan pelaku telah melakukan musyawarah bersama dan menghasilkan kesepakatan bahwa keluarga pelaku harus membayar Rp. 100.000.000,kepada keluarga korban, dan keluarga korban telah menyampaikan permintaan kepada penyidik untuk menghentikan proses hukum dan membebaskan tersangka, namun pihak penyidik tidak menerbitkan SP3 berdasarkan pertimbangan pimpinan.

26 Patty, J. (2020). Tindak Kekerasan Terhadap Anak di Lingkungan Satuan Pendidikan dan Peranan Keluarga Sebagai Upaya Non-Penal Dalam Pencegahan. JURNAL BELO, 5(2), $115-129$. https://doi.org/10.30598/belovol5issue2page115-129 


\section{Penutup}

Penerapan konsep restorative justice dalam Penanganan Kasus Kekerasan Terhadap Perempuan di Maluku dalam masa pandemi Covid 19 tetap dilakukan sebagaimana biasanya dilakukan dalam masa-masa sebelum pandemic covid 19. Untuk kasus-kasus yang melibatkan anak perempuan sebagai korban pelecehan seksual, sebagian besar kasus tidak diselesaikan dengan mekanisme tersebut. Faktor yang mempengaruhi penerapan konsep restorative justice terhadap kasus kekerasan terhadap perempuan di Maluku adalah tersedianya mekanisme hukum adat yag menunjang penyelesaian kasus melalui restorative justice, namun pada pihak lain, aparat penegak hukum mempertimbangkan asas kepentingan terbaik untuk anak yang menjadi korban, dan membuat jera pelaku, meskipun secara hukum adat telah diselesaikan melalui sistem hukum adat. Oleh karena itu, penerapan restorative justice untuk kasus kekerasan dalam rumah tangga terutama kekerasan terhadap istri dapat dilakukan sebagai pertimbangan untuk mempertahankan keutuhan keluarga, terutama melindungi masa depan anak, namun untuk kasus anak korban pelecehan seksual dan perkosaan sebaiknya diselesaikan tanpa menggunakan mekanisme restorative justice.

\section{Daftar Pustaka}

\section{Jurnal}

[1] Fadillah, A. (2019). Perlindungan Hukum Terhadap Anak Yang Menjadi Korban Aksi Perundungan. JURNAL BELO, 5(1), 86-100. DOI https://doi.org/10.30598/belovol5issue1page86-100

[2] Latumaerissa, D. (2020). Kajian Kriminologi Terhadap Kekerasan Yang Dilakukan Oleh Perempuan di Kota Ambon. JURNAL BELO,5(2), 57-73. DOI : https://doi.org/10.30598/belovol5issue2page57-73

[3] Leasa, E. (2019). Kekuatan Keterangan Saksi Sebagai Alat Bukti Pada Perkara Kekerasan Dalam Rumah Tangga. JURNAL BELO, 4(2), 188-203. DOI : https://doi.org/10.30598/belovol4issue2page188-203

[4] Patty, J. (2020). Tindak Kekerasan Terhadap Anak di Lingkungan Satuan Pendidikan dan Peranan Keluarga Sebagai Upaya Non-Penal Dalam Pencegahan. JURNAL BELO, 5(2), 115-129. DOI : https://doi.org/10.30598/belovol5issue2page115-129

\section{Buku}


[5] Abdul K. Muhammad, 2004, Hukum dan Penelitian Hukum, Citra Aditya Bakti, Bandung.

[6] Braithwaite, J. 2001, Shame Management Through ReintegrationCambridge University Press, Melbourne.

[7] Chaney, Daniel J and Claire m. Renzetti, 2005, Sosial Problem, Buston:allyn and bacon

[8] Curtis-Fawley, Sarah, and Kathleen Daly. 2005. "Gendered Violence and Restorative Justice: The Views of Victim Advocates." Violence Against Women 11(5)

[9] Elsa R.M. Toule, 2011 Penanggulangan Kekerasan Dalam Rumah Tangga (Suatu Pendekatan Yang Terintegral) Unpad Press, Bandung.

[10] Eva Achjani Zulfa, 2011, Pergeseran Paradigma Pemidanaan, Lubuk Agung, Bandung.

[11] H. Zehr and B. Toews (eds) 2002, Critical Issues in Restorative Justice, Monsey, NY: Criminal Justice Press.

[12] Loretta Frederick and Kristine Lizda, 2010 "The Role of Restorative Justice in the Battered Women's Movement ", in Restorative Justice And Violence Against Women edited by James Ptacek, Oxford University Press.

[13] Mansoer Fakih, 1996, Analisis Gender dan Transformasi Sosial, Pustaka Pelajar, Yogyakarta.

[14] Marian Liebmann, 2007, Restorative Justice, How it Works, Jessica Kingsley Publisher, London and Philadelphia.

[15] Marilyn Fernandez, 2010, Restorative Justice for Domestic Violence Victims, An Integrated Approach to Their Hunger for Healing, Lexington Books, United Kingdom.

[16] Moerti Hadiati Soeroso, 2010 Kekerasan dalam Rumah Tangga dalam Perspektif Yuridis- Viktimologis, Sinar Grafika Jakarta.

[17] Nurani Perempuan Women's Crisis Center (NPWCC), Kamis 18 Juli 2020.

[18] Satjipto Rahardjo, 1980, Hukum dan Masyarakat, Angkasa, Bandung

[19] Soerjono Soekanto, 1986, Pengantar Penelitian Hukum, Universitas Indonesia, Jakarta, 1986.

[20] Stephanie Coward, "Restorative Justice in Cases of Domestic and Sexual Violence: Healing Justice." Abuse Info and Resources. 2002, accesed 29 Oktober 2019 www.hotpeachpages.net/canada/air/rj_domestic_violence.html. 
[21] United Nations Commission on Crime Prevention and Criminal Justice, Basic Principles on the Use of Restorative Justice Programmes in Criminal Matters. Vienna: UN. 2002

[22] United Nations, Handbook on Restorative Justice Programmes, New York: United Nations Publication, 2006)

\section{Lain-Lain}

[23] Badan Pembinaan Hukum Nasional Kementerian Hukum Dan HAM RI Tahun 2013 Pengkajian Hukum Tentang Penerapan Restorative Justice Dalam Penyelesaian Tindak Pidana Yang Dilakukan Oleh Anak-Anak, Jakarta, 2013

[24] CNN Indonesia,Yasonna: Pembebasan Narapidana saat Corona Rekomendasi PBB, Jumat, 17/04/2020

[25] Liputan 6.com, 39.876 Napi Asimilasi Dibebaskan di Tengah Wabah Corona hingga 27 Mei 2020, 27 Mei 2020

[26] Zainal Abidin, Peluang dan Tantangan Restorative Justice [RJ] di Indonesia, Seminar Nasional "Mendorong Restorative Justice dalam Pembaruan Hukum Pidana di Indonesia: Menggali Pemikiran Prof. Mardjono Reksodiputro, S.H., M.A. dalam Pembaruan Hukum Pidana Indonesia" 17 Juli 2019 